\title{
oAKnín, Mazal. Feminism, Writing and the Media in Spain. OXFORD, PeTER LANG, 2019, 209 PP., ISBN 978-3-0343-1865-5
}

In line with the sociological shift in translation and literary studies, which is experiencing increasing success nowadays, Professor Mazal Oaknín offers us an essential work to delve into the evolution of women's writing in Spain in the twentieth century and how it is represented and constructed through the media. Unlike descriptive research focusing on cultural products, this scholar bases her research on the influence that historical context and marketing constraints have exerted on the image through which three emblematic female Spanish writers (Ana María Matute, Rosa Montero and Lucía Etxebarría) have introduced themselves to the world of letters and their readerships.

The author leaves nothing to chance and sets out the information meticulously by selecting an outstanding female writer for each sociohistorical stage in Spain: (i) the post-Civil War dictatorship; (ii) the Transition to democracy; and (iii) the period of post-Transition, Europeanisation and globalisation. Her proposal goes from the general to the particular, following a method of "concentric circles": firstly, she starts by conceptualising "female writing" in the world, then continues by analysing how Spanish female writers have shown themselves to their readers and intellectual audience. Next, she moves on to examine the construction of Matute's, Montero's and Etxebarría's personae and the response they have each individually given to the question of the existence or not of so-called "female writing".

In the 1st chapter, "The Question of 'Women's Writing': A 'DoubleEdged' Double Bind?", the author introduces the feminist ideological trend and the vision of literature written by women outside Spain, providing a rich plethora of references. Then she extrapolates this debate to Spain. In both cases, she displays masterful research work, opening up questions about the 'double-edged' catch implied by the recognition of a female literary form: making it more visible while placing it in a literary ghetto. Moreover, from the very first chapter she includes a conscientious study on news published in the Spanish literary magazine Qué leer to confirm or refute the famous statement made by another Spanish writer, Almudena Grandes: "Women writers are constantly forced to comment on the gender of the characters in their books, whilst male writers are enviably privileged and exempt from this" (p.18). Oaknín manages to quantify this reality by including all of the references to the compatibility of housework and literary work, and the relationship between female characters and female writers put forward in interviews published in the magazine from 2009 to 2012. 
She also uses Elaine Showalter's illustrative study Towards a Feminist Poetics (1979) to question the existence or not of a feminine literature that differs from the masculine one in Spain. The main approaches included in this publication to determine how differences according to sex can be established in literature are: the male-oriented tradition and the expulsion of women from "universal anthologies"; the experiences of life which, due to social conditioning, inevitably mark women's writing; and the formal or structural disparity of a "feminine" style as opposed to another "masculine" one.

In Chapter 2, "The Reception and Marketing of Women Writers in Spain", she introduces devastating numbers about the disparity between the amount of Spanish women Arts graduates and the low number of female writers in the literary world. There is also another aspect that constrains the work of women writers: the prejudice in reviews about their work, as it seems that a political stance or autobiographical projection is expected in their novels.

To support this premise, Oaknín introduces a second corpus of study based on the same Spanish magazine mentioned above, Qué leer. In this case, she includes interviews with female and male writers held between 2010 and 2012. Especially illustrative is Oaknín's analysis of the mise en scène of photographic material, burdening women with a closer, more personal and homely look as opposed to the aseptic professional appearance of men. This multimodal material confirms the suspicions expressed by the researcher in the previous chapter, which are rooted in Barthes's postulates about the absence of neutrality in cultural artefacts and practices that are commodified: the interest of the publishing market blurs the boundary between women writers' personae and their characters (pp.57-58).

Chapter 3, "The Literary Market and the Construction of the Public Personae and Women Writers", represents the core of the book. It is subdivided into three sections in which the history of the "women's writing label" is studied in detail through the figure of a reluctant Matute; the protesting yet free figure of Montero, who intended to establish a separation between her political ideas and her writing; and finally, Etxebarría's prototypical and hyperbolic stance as one of the main supporters of "women's writing" and "feminism" in the Spanish literary market.

Although Matute had to find her way in a masculinised battleground and for years endured an image stigmatised by her association with the children's writer label and by the suggestion that her invitation to the Royal Academy was undeserved, she has escaped from the clutches of a publishing market that makes the "feminisation" of literature and the inclusion of snippets of the 
writer's personal life a sine qua non condition for launching and disseminating literature written by women.

For her part, Montero's literature was born out of a period of transition: from the publication of her Crónica del Desamor, which reflects the pressing need to address contemporary political and legal issues facing women, to her winning the Premio Primavera de Novela award in 1997, which led to her experiencing the growing commercialism of the Spanish literary market and the increasing pressure on authors to meet its demands. Indeed, she had to work hard to keep the press out of her "domestic life" (p. 99).

Finally, Lucía Etxebarría is an example of a writer who actively builds her own persona in the virtual world. However, an excessive degree of overexposure has led her to lose control over "the process of negotiating and re-negotiating the construction of her celebrity persona" (p.119). In her books, she addresses a portrait of post-modern Spanish society with references to American and popular culture, an unabashed usage of colloquial and vulgar language, unreserved descriptions of eroticism and female sexuality, drug use and the apathy of a generation for whom many social standards have been shattered. Etxebarría's website acknowledges "the need to create alternative contemporary models of femininity". Indeed, Amor, curiosidad, prozac y dudas is an ode to Generation X women. Unfortunately, as a star author who is expected to achieve as many readers as possible, Etxebarría turns out to be a woman in a "marketplace that privileges men and exploits the multimedia representation of the author, who is not immune to the sexualised and objectified mass media approach to the female body" (p.111). Through her example we will see how, despite the fact that the grip of Franco's constraints has already been loosened, the market is looking for new ways to exploit and objectify women, even through the paradoxical label "feminist writing".

Finally, in Chapter 4, "Response of the three writers to the question of the existence (or not) of 'women's writing' ", it is the writers themselves who look in the mirror and answer about their view of female writing. In this sense, it is interesting to realise how the first post-Civil War writers shunned this label while the more contemporary ones claim it.

In conclusion, this is a serious, consistent study with a method that can be replicated in the near future to confirm whether the situation of these three emblematic writers is the one experienced by other female writers both in Spain and other countries. The results will also allow us to identify why certain sexist prejudices have not disappeared but are reinforced through simplistic marketing which, instead of adding new voices to the traditional repertoire, falls into the terrible contradiction of selling a poisoned apple of the usual prejudices. In addition to an extensive bibliography, the author offers us a 
contemporary multimodal analysis that shuns prescriptivism and shows us the less friendly side of gender labels. I consider that this is the direction that new studies on gender and women's literature should take: not to hide or sugarcoat but to use all of the methodological resources available to openly show violence and segregation, without falling back on hackneyed models that portray the literary corpus by women as an exotic phenomenon satisfying a voyeuristic impulse without interpreting or including it as one of the true faces of an increasingly diverse society and literature.

[MARÍA LUISA RODRÍGUEZ MUÑOZ] 